\title{
Considerations on the correlation between real body and body image
}

\author{
Beatrice ABALAȘEI ${ }^{1}$, Florin TROFIN ${ }^{2}$
}

\begin{abstract}
Every individual in the society has a representation of it's own body in relation to the spatial cues, postural cues, time cues, etc., considered by specialists the body scheme. Throughout its development, the human being goes through different stages of organization of both the image the and body scheme. We start carrying out this study from the idea that there could be, in male individuals, a link between body representation (own image projected outwardly apparent by reference to an image presented through a questionnaire) and anthropological parameters, such as body fat and body mass index.

The study was conducted on a total of 28 subjects, aged $22.71 \pm 2.62$ years, height of $177.11 \pm 6.76 \mathrm{~cm}$ and body weight of $73.56 \pm 12.60 \mathrm{~kg}$. For these subjects the body composition has been determined by electromagnetic bioimpendance technique and projection of the self was assesed through a questionnaire.

After analyzing statistical data, our hypothesis was refuted by the lack of mathematical connections between the variables analyzed.
\end{abstract}

Key words: body schema, representation, body mass index.

\section{Rezumat}

Fiecare individ al societății are o reprezentare despre propriul corp în relația cu reperele spațiale, posturale, temporale etc., aceasta fiind considerată de specialiști schema corporală. De-a lungul dezvoltării sale, individul trece prin diferite etape de organizare a imaginii și schemei corporale. Demersul investigativ pleacă de la ideea că ar putea exista, la actorii sociali de gen masculin, o legătură între reprezentarea corporală proprie (imaginea proprie proiectată în exterior, evidentă prin raportarea la o imagine prezentată prin intermediul unui chestionar) și parametri antropologici, precum grăsimea corporală și indicele de masă corporală.

Studiul a fost realizat pe un număr de 28 de subiecți, cu vârsta de 22,71 $\pm 2,62$ ani, înălțimea de 177,11 $\pm 6,76 \mathrm{~cm}$ și masa corporală de 73,56 $\pm 12,60$ kg. Subiecților le-a fost determinată compoziția corporală prin tehnica bioimpendanței electromagnetice și proiectarea sinelui spre exterior prin aplicarea unui chestionar.

În urma procesării statistice a datelor obținute, ipoteza noastră a fost infirmată de lipsa legăturilor matematice dintre variabilele analizate.

Cuvinte cheie: schema corporală, reprezentare, indici de masă corporală.

\footnotetext{
${ }^{1}$ Assoc. PhD, Physical Education and Sport Faculty, Alexandru Ioan Cuza University, Iași; email: beatrice.abalasei@uaic.ro

2 Prof., Physical Education and Sport Faculty, Alexandru Ioan Cuza University, Iași
} 


\section{Introduction}

Knowledge focuses on the explanations given by social actors when they come into contact the phenomena of the world, with their unpredictable and impressive events. Hence, there are key processes that stimulate knowledge for social integration, processes that refer, first of all, to the desire of understanding each other in relation with individuals, by referring to the social discourse, by the desire of getting to know the other, an alter endowed with symbolic meanings within the culture. The fundamental function of the symbol is to determine people, to decipher the meanings of abstract contents within the accumulated experience; it allows the social actors to feel what they see as a complicated scenario and to make a summary of it in a social framework. Consequently, this study leads us toward an area where a social model, alter, becomes a model within its own modelling, in the individual development process. In this case, alter can also be the object, the projection or our wish to evolve. Thus, we project to the exterior a representation subordinated to the system of values and norms belonging to the individual or to his/her group. On the other hand, representation does not have a predetermined significance, but it represents the subject/object relationship (self-alter).

In our opinion, external representation means the view of a segment of the world which provides an individual with the possibility of ascribing a meaning to his/her behaviours and of understanding reality through his/her own universe of principles and beliefs, of adapting to the community. Common people do not perceive reality from a normative perspective. They do not submit to logical or statistical information analysis models; they ignore certain information; they exaggerate others; they over-generalize. These information processing deviations have cognitive causes (limited information processing capacity), social causes (social norms, rules) and motivational causes (wish for high self-esteem). Reality interpretation and deciphering takes into account a rational algorithm, but also social rules. The social nature of representations has been defined to the object represented; to the social context in which they are expressed; to consensus, to the origins in social interaction and communication; and their relations with the social system and with the social reality of cultural phenomena such as language, books, and other human products [1]. The cognitive mechanisms represent the rational component, governing information processing (associations, inclusions, and dissociations), while the social component (meta-system) accelerates these mechanisms; they control, assess, and select information and the processes transforming them by social norms and rules, as well as by the individual system of values.

Self-representation - projected outward and retrieved in the others - has the capacity of submitting to cognitive and social logic and it may be described in terms of socio-cognitive constructs, based on specific rules and the characteristic of integrating both the rational (cognitions, beliefs) and the irrational (culture, tradition).

According to Alfried Längle, our self becomes visible only through other objects and contents that it influences, hence the indissoluble connection between the self and the alter through which the self identifies [2].

In conclusion, the focus here concerns body schema, which is the representation of each individual on his/her own body taking into account spatial, postural and temporal ("three-dimensional selfimage") references; in this sense, alter is a good model.

The ultimate synthesis of the body image development is the perception of one's own body as unique and different from that of the others, the perception of the self as object and subject.

The organization of body image and body schema comprises several stages $[3,4]$ :

- Seeing the body: similar to the body discovery stage, where each individual perceives, sees the body as a whole. It refers to the way in which man moves freely and discovers the action of segments without naming them. It begins around the age of two years and a half, when the experience of balanced gait also contributes to the discovery of space.

- Perceiving the body: man learns the different parts of the body through 
experiences, lives in the relationship with the self, the environment, and others (this stage ends around the age of six).

- Representing the body: it refers to a person's maturity, to the stage when environment provides enough knowledge alternatives to integrate partial synergies and to execute a harmonious movement.

Body schema formation depends on the following: acquisition of temporal orientation, laterality, language, and reflected image.

In this sense, body schema represents more than the acquisition of perceptive data representations, because it memorizes information to define body the unit.

\section{Objective of the study}

We intend in this study to analyze whether there is a relationship between the represented body and the real body, among male subjects, aged between 19 and 30 years.

\section{Study hypothesis}

Among male subjects, aged between 19 and 30 years, we estimated that there is a similarity between the represented body by reference to the alter, and the real body, expressed by anthropological parameters.

\section{Research variables:}

External representation of the self - dependent variable;

Body fat and body mass index - independent variables.

Advances made in biomedical evaluation technology led to the creation of methods to assess all body components on atomic, molecular, cellular, and tissue level. At the beginning, the two components determined in terms of body composition were body fat and lean mass, and more components were added gradually (water, minerals, visceral fat) [5]. The practical experimentation of modern assessment methods led to continual improvements. The latest methods involve threedimensional photonic scanning, but this technique is not widely accessible. The most common method is electrical bioimpedance [6].

The health status of a human being can be assessed using body mass index (BMI), because its normal values range between 18.5 and $24,9 \mathrm{~kg} / \mathrm{m}^{2}$ ) [7, 8]. Under $18 \mathrm{~kg} / \mathrm{m}^{2}$, BMI indicates a lack of balance between weight loss and the energy reserves of the body, which leads to pathologies $[9,10,7]$.

Attempts have been made to find a correlation between Body fat and $\operatorname{BMI}(11,12)$, taking into account that it may vary due to factors such as age, gender, body shape, ethnic group, etc $[13,14,15$, 16].

It is important to know the BMI during childhood and adolescence, because high values are associated to pathologies and even to death $[17,18,19,20,21]$. It has been proven that BMI can be modified by physical effort (at least four hours/week of walks or easy runs). The aspect of body modification was explained subsequently by a study that compared forest workers and researchers: the first category ranged better, within normal limits [22].

\section{Subjects}

The volunteers included in the study are male, aged between 19 and 30 (28 subjects). Their characteristics are featured in Table I.

Table I. Characteristics of the experimental group (mean \pm standard deviation)

\begin{tabular}{ll}
\hline Characteristic & Value \\
\hline Age (years) & $22.71 \pm 2.62$ \\
\hline Number of subjects & 28 \\
\hline Height $(\mathrm{cm})$ & $177.11 \pm 6.76$ \\
\hline Weight $(\mathrm{kg})$ & $73.56 \pm 12.60$ \\
\hline Body fat $(\%)$ & $16.25 \pm 7.24$ \\
\hline Physical activity level (1-5) & $2.29 \pm 0.76$ \\
\hline
\end{tabular}

\section{Materials and methods}

The investigation method used a questionnaire meant to show the image of each subject about his own person. The number of items was limited to 10 . The questionnaire was applied to 28 subjects, and Cronbach's Alpha coefficient of internal consistency was 0.653 . The value of the coefficient of internal consistency demonstrates that the working instrument measures what we have proposed.

The images featured below (Fig. 1) are an important part of the questionnaire, because each respondent related his own body image to them. 


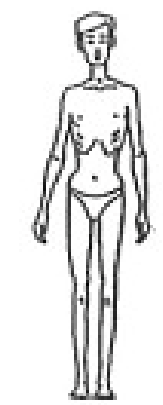

1

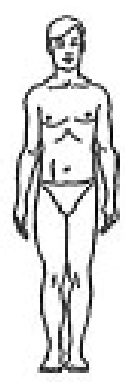

2
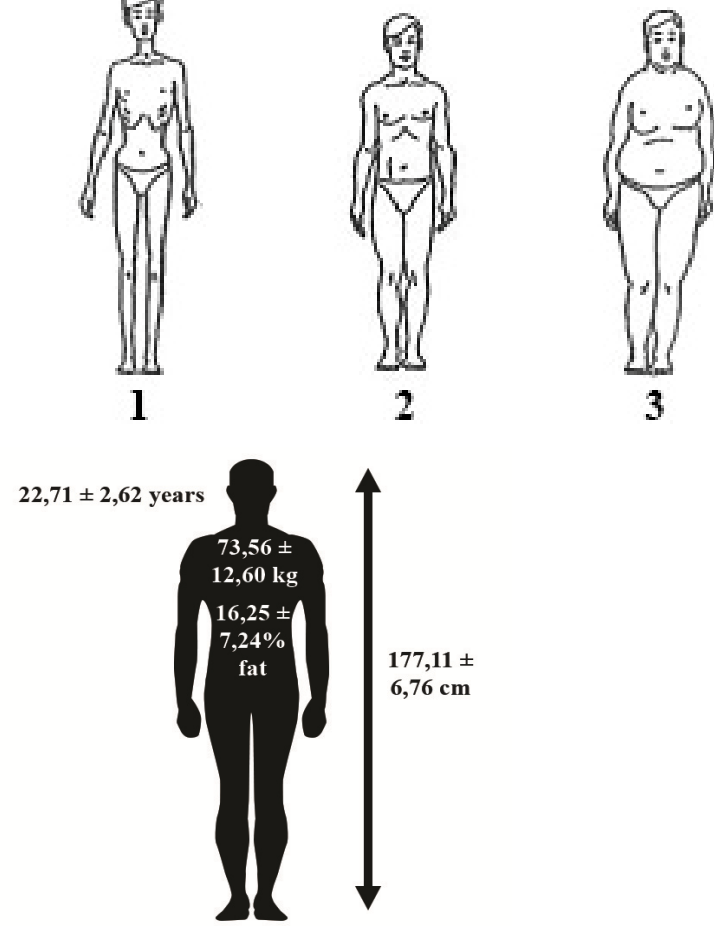

Figure 1. Body image models vs. Real body image

\section{Testing protocol for independent variables}

The method used to determine body composition is electrical bioimpedance (IBE), which involves submitting the body to the action of alternative currents of various frequencies [23]. The advantage is that the method is easy and quick [24]. Before body analysis, the height of each subject was measured. The subject stood next to a wall with $0^{0}$ inclination toward the vertical plane, on a floor with the same inclination toward the horizontal plane, in a normal anatomic stance. Height was determined by using a steel square $(20 / 40 \mathrm{~cm})$. A steel square (placed with one side on the wall and the other tangentially on the subject's top of the head) and a Bosch GLM80 angle measurer were used to determine the height.

The questionnaire

Questionnaire items, a total of ten, included reference to the presented image: an image that represents the body that is the nicest, most proportioned, most comfortable, most popular and most seductive.

Individual data (age, gender, instruction level, height) were introduced in the Tanita BC 587 scale, on which the subjects stepped when the display read 00 . The subjects wore only shorts and a T- shirt. They were barefoot; they stood on a rubber rug before the analysis, (for hygiene purposes). Subjects were required to stand during the procedure and to step away from the analyser after a beep. The results - Body fat (\%) included - were noted on the individual chart of each subject. Each subject had to drink one litre of water 1-2 hours before the analysis, to ensure hydration. In the event of any dehydration of the human subjects, the body analyzer can determine incorrect values in the muscle mass and body fat. BMI for each volunteer was determined very easily, as the result of the ratio between body mass and height squared.

It must be stated that the physical status of the subjects could be assessed according to the level of body fat (according to the standard of the device):

$$
\begin{array}{ll}
\text { - } & 0-8 \%=\text { underweight; } \\
\text { - } & 8-20 \%=\text { normal; } \\
\text { - } & 20-25 \%=\text { overweight; } \\
\text { - } & >25 \%=\text { obese. }
\end{array}
$$

BMI and body fat results show that our subjects belong to images 2 and 3, if proportions between body image model and classification standards concerning the two independent variables are preserved.

External representation of the self recorded a mean value of $1.96 \pm 0.13$. Upon analysing the subject from the perspective of independent variables, it is possible to have a discrepancy between the analysed aspects.

\section{Findings and discussions}

Table II. Correlation between research variables

\begin{tabular}{|l|l|l|l|}
\hline & & \multicolumn{1}{|c|}{$\begin{array}{c}\text { ERS } \\
\text { vs. } \\
\text { BMI } \mathbf{k g} / \mathbf{m}^{2} \text { ) }\end{array}$} & $\begin{array}{c}\text { ERS } \\
\text { vs. } \\
\text { Body fat (\%) }\end{array}$ \\
\hline Pearson r & & & \\
\hline ERS & & 0.1026 & -0.05324 \\
\hline $95 \%$ confidence & & -0.2814 to & -0.4181 \\
interval & 0.4582 & 0.3264 \\
\hline R square & & 0.01052 & 0.002834 \\
\hline P value & & & \\
\hline P (two-tailed) & & 0.6035 & 0.7879 \\
\hline P value summary & & ns & Ns \\
\hline Significant? (alpha & & & \\
\hline$=0.05)$ & & No & No \\
\hline Number of XY Pairs & & 28 & 28 \\
\hline
\end{tabular}


Upon analyzing the results, no correlation was found between External Representation of the Self (ERS) and the two independent variables analyzed: Body fat and body mass index (BMI) (Table II).

The link between ERS and BMI is not statistically significant; the 0.60 value of the significance threshold supports the independence of ERS concerning BMI.

The correlation between ERS and Body fat is not statistically significant; the significance threshold is 0.78, which demonstrates that ERS is not influenced by respondents' Body fat.

After analysing the possible connections between the independent variables and the dependent variable, graphs were elaborated for the linear regression between ERS and BMI, and Body fat, respectively (Figure 2 and 3). The distribution of values shows their dispersion and the fact that one cannot appraise the ERS level of individuals comprised within the statistical population of the study series only by knowing their BMI and Body fat.

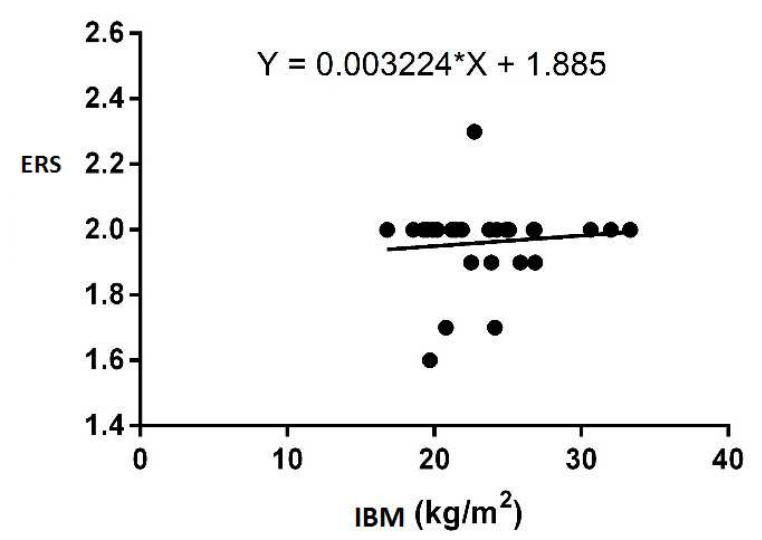

Figure 2. Linear regression between body mass index and ERS

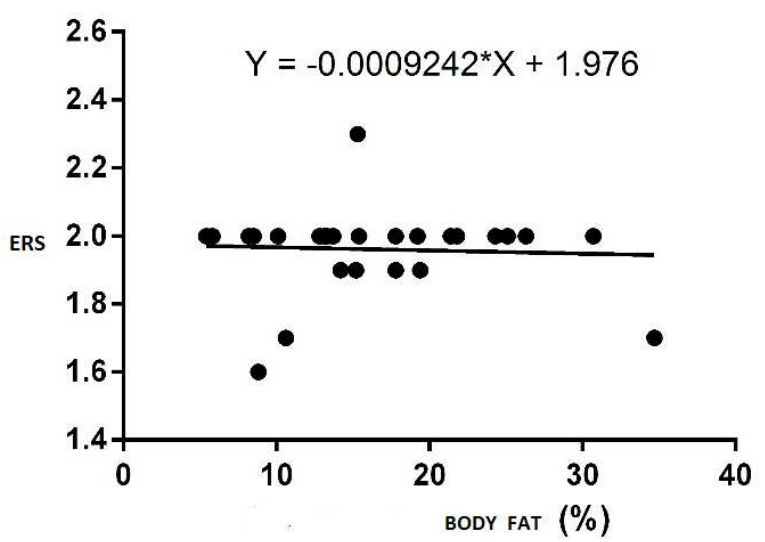

Figure 3. Linear regression between body fat and ERS

The literature does not contain any analysis of relations between body scheme of male individuals and their anthropometric parameters, this ensuring a high degree of originality of our work.

We hope to challenge researchers interested in this study niche to conduct similar studies, in order to create the possibility of reporting the results coming from different corners of the world, cultures etc.

\section{Conclusions}

Contrary to our expectations, research findings and their statistical analysis contradict the research hypothesis. It is possible for the male gender of subjects to have determined the lack of correlation between ERS and two of the descriptive parameters concerning the real body: BMI and Body fat. This aspect can underscore the dependence of ERS on other factors and not so much on the real body of the individuals included in the statistical population or our study series.

It is possible to develop such research by making comparisons between males and females, for instance (with the same demographic characteristics). An analysis can also be conducted for persons involved in performance sport, because their ERS can be different from the one of nonathletes.

\section{References}

1. Purkhardt S., Caroline, (1993). Answering and unanswered questions, The Motivational and Society in The Dynamics of Social Representations, Routledge, London. 
2. Längle A. (2006). Sinele ca zonă predilectă a disocierii şi scindării, Analiză Existenţială Nr. 5, anul VIII, Anxietate şi isterie, 33-56.

3. Albu A., Albu C., (1999). Psihomotricitatea - la vârsta de creştere şi dezvoltare, Ed. Spiru Haret, Iaşi.

4. Albu C., et al. (2006). Psihomotricitatea, Ed. Institutul European, Iaşi.

5. Heymsfield S.B., Gallagher D., Mayer L., Beetsch J. and Pietrobelli A. (2007). Scaling of human body composition to stature: new insights into body mass index, Am. J. Clin. Nutr., 86, 82-91.

6. Lee S.Y., Gallagher D. (2009). Assessment methods in human body composition, Curr. Opin. Clin. Nutr. Metab. Care, 11(5), 566-572.

7. World Health Organization (1995). Physical Status: The Use and Interpretation of Anthropometry, Report of a WHO Expert Committee, Technical Report Series No. 854, Geneva: World Health Organization.

8. Khongsdier R. (2005). BMI and morbidity in relation to body composition: a cross-sectional study of a rural community in North-East India, British Journal of Nutrition, 93, 101-107.

9. James W.P.T., Ferro-Luzzi A., Waterlow J.C. (1988). Definition of chronic energy deficiency in adults, Eur. J Clin Nutr., 42, 969-981.

10. Shetty P.S., James W.P.T. (1994). Body Mass Index: A Measure of Chronic Energy Deficiency in Adults, Food and Nutrition Paper, No. 56, Rome: FAO.

11. Frankenfield D.C., Rowe W.A., Cooney R.N., Smith J.S. and Becker D. (2001). Limits of body mass index to detect obesity and predict body composition, Nutrition, 17, 26-30.

12. Purkhardt S., Caroline, (1993). Answering and unanswered questions, The Motivational and Society in The Dynamics of Social Representations, Routledge, London.

13. Längle A.. (2006). Sinele ca zonă predilectă a disocierii şi scindării, Analiză Existenţială Nr. 5, 2006, Anul VIII, Anxietate şi isterie, 33-56.

14. Albu A., Albu, C., (1999). Psihomotricitatea - la vârsta de creştere şi dezvoltare, Ed. Spiru Haret, Iaşi.

15. Albu C., et al. (2006). Psihomotricitatea, Ed. Institutul European, Iaşi.

16. Heymsfield S.B., Gallagher D., Mayer L., Beetsch J. and Pietrobelli A. (2007). Scaling of human body composition to stature: new insights into body mass index, Am. J. Clin. Nutr., 86: 82-91.

17. Lee S. Y. and Gallagher D. (2009). Assessment methods in human body composition, Curr. Opin. Clin. Nutr. Metab. Care, 11(5): 566-572.

18. World Health Organization (1995). Physical Status: The Use and Interpretation of Anthropometry, Report of a WHO Expert Committee, Technical Report Series No. 854., Geneva: World Health Organization.

19. Khongsdier R. (2005). BMI and morbidity in relation to body composition: a cross-sectional study of a rural community in North-East India, British Journal of Nutrition, 93, 101-107.
20. James W.P.T., Ferro-Luzzi A. and Waterlow J.C. (1988). Definition of chronic energy deficiency in adults, Eur. J. Clin. Nutr., 42, 969-981.

21. Shetty P.S. and James W.P.T. (1994). Body Mass Index: A Measure of Chronic Energy Deficiency in Adults, Food and Nutrition Paper, No. 56, Rome: FAO.

22. Frankenfield D.C., Rowe W.A., Cooney R.N., Smith J.S. and Becker D. (2001). Limits of body mass index to detect obesity and predict body composition, Nutrition, 17, 26-30.

23. Kyle U.G., Schutz Y., Dupertuis Y.M. and Pichard C. (2003). Body composition interpretation: contributions of the fat-free mass index and the body fat mass index, Nutrition, 19, 597604.

24. Norgan N.G. (1994). Population differences in body composition in relation to the body mass index, Eur. J. Clin. Nutr., 48, 10-27.

25. Gurrici S., Hartriyanti Y., Hautvast J.G. and Deurenberg P. (1998). Relationship between body fat and body mass index: differences between Indonesians and Dutch Caucasians, Eur. J. Clin. Nutr., 52, 779-783.

26. Wagner D.R., Heyward V.H. (2000). Measures of body composition in blacks and whites: a comparative review, Am. J. Clin. Nutr., 71, 1392-1402.

27. Prentice A.M., Jebb S.A. (2001). Beyond body mass index, Obes. Rev., 2, 141-147.

28. Abraham S., Collins G. and Nordsieck M. (1971). Relationship of childhood weight status to morbidity in adults, HSMHA Health Rep., 86, 273-284.

29. Baker J.L., Olsen L.W., Sorensen T.I.A. (2007). Childhood body-mass index and the risk of coronary heart disease in adulthood, N. Engl. J. Med., 357, 2329-2337.

30. Bjorge T., Engeland A., Tverdal A. and Smith G.D. (2008). Body mass index in adolescence in relation to cause-specific mortality: a follow-up of 230.000 Norwegian adolescents, Am. J. Epidemiol., 168, 30-37.

31. Mossberg H.O. (1989). 40-Year follow-up of overweight children, Lancet, 2, 491-493.

32. Franks P.W., Hanson R.L., Knowler W.C., Sievers M.L., Bennett P.H. and Looker H.C. (2010). Childhood obesity, other cardiovascular risk factors, and premature death, $\mathrm{N}$. Engl. J. Med., 362, 485-493.

33. Gallis C. (2009). Body composition and obesity among Greek forest workers and researchers, International Journal of Body Composition Research, 7(3), 85-89.

34. Bedogni G., Bellentani S., Miglioli L., Masutti F., Passalacqua M., Castiglione A. and Tiribelli C. (2006). The Fatty Liver Index: a simple and accurate predictor of hepatic steatosis in the general population, BMC Gastroenterol., 2, 6-33.

35. Forbes G. B. (1999). Longitudinal Changes in Adult Fat-Free Mass: Influence of Body Weight, The American Journal of Clinical Nutrition, 70(6), 1025-1031. 